\title{
EFFECT OF DVI-AVARTITA BHRINGARAJA TAILA IN DUSHTHA VRANA (CHRONIC INFECTED ULCER)
}

\author{
Goli Penchala Prasad ${ }^{1 *}$, C. Murali Krishna ${ }^{2}$, S. Pavan Kumar ${ }^{3}$, \\ G. Tirumal ${ }^{3}$, A. Narayana ${ }^{4}$
}

\begin{abstract}
Dushtha vrana (chronic infected ulcer) was mentioned as one of the types of Vrana (wound/ ulcer). Sushruta in his Sushruta samhita, a representative treatise of Indian school of surgery, devoted many chapters for the description and management of Vrana. According to modern medicine and recent researches the etiology and pathogenesis of wound and its healing involves many systemic, local, and molecular factors. Foreign bodies, tissue maceration, ischaemia, infection, systemic factors like advanced age, malnutrition, diabetes, and renal disease are some among them. Ayurveda advocates both internal and external therapies for the management of Vrana. Upward and downward evacuation, fasting, de-saturating diet, blood letting, washing of the wound with medicated decoctions, external application of medicated oils etc. are some among them. Though many factors involves in wound healing, the complex interaction between epidermal and dermal cells and the extra cellular matrix are considered to play an important role. Based on this fact and in order to simplify the treatment, as per the classical references Dvi-avartita Bhringaraja taila was selected for the present study. Fifteen patients of chronic infected ulcers of variant etiology with common features like ulcer with foetid pus, oozing, pain etc. were selected for the present study. Out of 15 cases, $8(53.33 \%)$ got good response, $5(33.33 \%)$ got fair response, $1(6.67 \%)$ got poor response and $1(6.67 \%)$ case had no response. Parameter wise $80.00 \%$ of relief in pain, $73.17 \%$ in curing of Pus discharge, $81.08 \%$ in curing of Foul smell, $78.79 \%$ relief in Oedema/ induration and $65.00 \%$ Reduction of ulcer were found. Over all $69.52 \%$ relief was found by assessing all parameters. Statistical analysis of the mean difference before and after treatment in relief on all the above symptoms were found highly significant $(\mathrm{P}<0.0001)$.
\end{abstract}

Keywords: Dushtha vrana, chronic ulcer, Bhringaraja taila,

\section{Introduction:}

Healing of ulcers and wounds from injuries represents a basic response of the living tissue. Because of different conditions of wound, natural pattern of healing of wounds is not uniform. Wound healing is retarded by local factors and systemic diseases. Local factors such as infection, pus, slough, blood supply, radiation, foreign bodies, site of wound, etc. hinder the process of natural wound healing. Similarly, systemic diseases like tuberculosis, diabetes, malignant diseases, jaundice, hypertension and various other systemic factors like aging, malnutrition and other factors like economic status and occupation will have remote effect on the wound by retarding the sequence of healing process.

$1 *$. Corresponding author: Assistant Director, National Institute of Indian Medical Heritage, Hyderabad,

Tel: +919441654500, E.mail: drprasadgoli@yahoo.com

2.Research Officer (Ayurveda), 3.SRF (PhD) (Ayurveda), 4.Director, NIIMH, Hyderabad 
According to Sushrut "The destruction /break/rupture /discontinuity of body tissue / part of body, is called Vrana." (Vrana Gatra Vichurnane, Vranayati iti Vranaha. Su.Ch1/6). Dusta means durbala (unhealthy) or Adhamah (degraded), damaged, spoiled, injured, deprived etc. Classification of wounds, their prognostic evaluation and management was most scientifically described in Sushruta samhita.

According to Acharya Sushruta the ulcer is called as Dusta vrana when it has the following features (1) Viz. (Figure:3-6 to identify some of the features of Dushta vrana)

1 Ati samvrutha - too narrow.

2 Ati vivrutha - too wide.

3 Ati katina - too hard.

4 Ati mrudu - too smooth.

5 Utsanna - elevated

6 Avasanna -depressed.

7 Ati sita -too cold.

8 Ati usna -too hot.

9 Krishna, Rakta, sukla, Bhairava (black, red, white, and looks ferocious).

10 Puti puya, mamsa, sira, snayu (pus with bad odor due to vitiated muscular content of the wound).

11 Puti puya srava - foul smelling purulent discharge

12 Unmarga -spreading in different directions.

13 Utsanga -having deep base.

14 Amanojna gandha -foul smell.

15 Atyartha vedana -excessive pain.

16 Daha, paka, raga, kandu, sopha (burning sensation, suppuration, redness, itching, inflammation).

17 Upadrava -associated with complications.

18 Atyartha dusta sonita srava excessive oozing of blood admixed with pus etc.
19 Deerga kalanubandhi-chronic.

Acharya Charaka described the dustavrana features as following (2)

1 Shwetha - white

2 Avasanna vartma - skin on the wound is not at the same level of the adjacent)

3 Sthula vartma - skin over the wound is above the level of adjacent skin

4 Ati pinjara - deep yellow coloured

5 Nila, shyava - blue, brown coloured

6 Ati pidaka - excessive blister formation

7 Rakta, Krishna - red and black coloured

8 Ati putika - having putrefied smell.

9 Kumbhi mukha - opening of the wound is like a pot and also

10 Putighandha - rotten smell

11 Vivarna - pale/bad coloured

12 Bahusrava -excessive secretion

13 Mahruja -severe pain.

Based on the above features dushta vrana of Ayurvedic literature can be correlated with chronic infected ulcer of contemporary modern medicine.

\section{Ayurvedic line of treatment}

Upward and downward evacuation (Vamana and virecana), fasting, de-saturating diet and blood letting are advised. Decoction of Aragvadhadi and surasadi drugs are advised for washing the wound and oil prepared with the decoction of the same drugs or with alkali water or alkaline plants are indicated for cleansing the wound(3).

\section{Selection of Drug:-}

Many internal and external drugs and formulations are mentioned in classical Ayurvedic literatures for the treatment of Dushtha vrana. Though many factors involve in etiopathogenesis and healing of the Dushtha 
vrana, interactions between epidermal and dermal cells and the extra cellular matrix are considered to play an important role. Based on this fact and after verifying both classical and contemporary literatures Dvi-avartita Bhringaraja taila was selected for the present study as an external application.

\section{Rationale in selection of Drug}

Externally it has sothahar (anti oedema/inflammatory), vedanasthapan (analgesic), vranasothan (wound cleaning), vranaropan (wound healing), savarnikaran (normalizing the colour/ turns the skin to earlier normal colour) properties). (4)

It is considered antiinflammatory and pharmacologically it's antiviral, antibacterial, analgesic, and anti hemorrhagic properties were also proved (5).

Oil cooked with juice of Bhrungaraja (Eclipta alba Hassk) is indicated in sinuses caused by kapha and vata scrofula and wounds (3).

According to Gada Nigraha, Bhrungaraja juice is used for washing wounds (vranadhavana) in soft chancre (upadamsa) and ulceration in venereal diseases (6).

As per Bhava prakash, Pancha nimba churna impregnated in Bhrungaraja expressed juice is indicated in kushtha rogas (obstinate skin diseases), eruptions (visphota), erysipelas (visarpa), cervical adenitis (gandamala),

fistula-in-ano (bhagandara), sinus (nadivrana) and various other diseases (6).

According to Bhaishajaya Ranavali, Bhallatkadya taila which contains Bhrungaraja svarasa (expressed juice of herbs) as a major component is indicated in nadivrana (sinus), the oil, scrofula (apaci), wound (vrana) and allied ailments (6).

The above descriptions clearly supports that Bhrungaraja taila has definite wound cleansing (vrana shodhana) and healing (vrana ropana) properties. Here in this study dvi avartita Bhrungaraja taila is used to strengthen the properties of oil and to get fast results.

\section{Mode of preparation of oil}

Whole plant of Bhrungaraja (Eclipta alba Hassk) (Figure 1) was washed with clean water to remove mud and other physical particles. 4 liters of expressed juice of the whole plant was boiled after mixing with 1 liter of sesame oil and 250 gm of same plant paste, till oil remains. Thus obtained oil was once again boiled with same procedure to get Dviavartita Bhrungaraja taila (Figure 2).

\section{Materials and Methods} Aims and Objects

1. To assess the overall efficacy of Dviavartita Bhrungaraja taila in curing the Dushta vrana

2. To assess the efficacy of Dviavartita Bhrungaraja taila in curing various clinical signs and symptoms of the Dushta vrana

\section{Criteria for Selection of the patient}

As in modern medicine there are various types of chronic infective ulcers, the patients for the present study were selected based on the features of Dushta Vrana, mentioned in Ayurvedic classics. Irrespective of their associated diseases and disorders based on the main clinical features the patients were selected.

1. Patients of either sex in between 1560 years of age 
2. Patients of Dushta vrana with above 6 months chronicity

3. Dushtha vrana with features like inflammation, Discharge of pus, debris with foul smell, excruciating pain and edema over surrounding area, Presence of slough with no evidence of granulation tissue, spreading in nature with no defined edges and floor.

\section{Criteria for Exclusion}

1. Patients of the age below 15 years and above 60 years of age.

2. Patients of Dushta vrana with below 6 months chronicity.

3. Patients with known history of Malignancy, venereal diseases and other chronic and infective ailments.

\section{Criteria for with drawn}

1. Patients left the treatment in between

2. Suffered from any serious illness during the treatment

Criteria for the assessment of the response after the therapy:

Specific scores were denoted against each and every parameter was recorded initially and during subsequent assessments i.e. every 15 th day up to 60 days.

\section{Pain}

$\begin{array}{llll}\text { a. } & \text { Severe } & - & 3 \\ \text { b. } & \text { Moderate } & - & 2 \\ \text { c. } & \text { Mild } & - & 1 \\ \text { d. } & \text { No pain } & - & 0\end{array}$

\section{Pus discharge}

a. Severe $\quad-\quad 3$

b. Moderate - 2

c. Mild $\quad-\quad 1$

d. No discharge - 0

\section{Foul smell}

$\begin{array}{llll}\text { a. } & \text { Severe } & - & 3 \\ \text { b. } & \text { Moderate } & - & 2 \\ \text { c. } & \text { Mild } & - & 1 \\ \text { d. } & \text { No Foul smell } & - & 0\end{array}$

4. Oedema / Induration

a. Present $\quad-\quad 2$

b. absent - $\quad 0$

5. Reduction of ulcer area

a. before treatment (total - 20 ulcer area)

b. reduction of $25 \%$ to $50 \%-15$ ulcer area

c. reduction of $51 \%$ to $75 \%-10$ ulcer area

d. reduction of $76 \%$ and -5 above ulcer area

e. reduction of $100 \%$ ulcer - 0 area

Basing on the individual score of each finding before and after treatments, the response of the treatment can be assessed. Over all effect of the treatment in each individual patient can be assessed by the below formula.

i.e. over all percentage of relief $=$ (Total score of all findings before treatment -Total score of all findings after the treatment) X $100 /$ Total score of all findings before treatment

\section{Classification of the Results:}

i. Good Response: $75 \%$ or more relief in clinical symptomatology

ii. Fair Response: $50 \%$ to $75 \%$ relief in symptomatology.

iii. Poor Response: $25 \%$ to $50 \%$ relief in symptomatology.

iv. No Response: Relief below $25 \%$ in symptomatology

Drug: Dviavartita Bhrungaraja taila.

Dosage: Sufficient quantity applied externally twice a day and allowed for at 
least four hours either directly or dipping in a gauze plug.

Duration of treatment: 60 days

Type of the study: open clinical trail

\section{Investigations}

Investigations of the following routine investigations were done to all the patients before and during subsequent intervals, however specific investigations were done to assess the condition of particular individual patients wherever necessary. The results of investigations were not included in the assessment of results as the Total study was planned on Ayurvedic parameters.

Routine investigations:

a. Blood-CBP and ESR

b. Urine-Complete analysis

c. Stool-Routine examination

Special investigations:

a. Bio-chemical - I) Blood sugar (ii) VDRL

b. Bacteriological - Cultural and sensitivity of discharge

c. Histo-pathological

d. Radiological- Plain X-Ray films of the affected parts were taken according to the necessity.

\section{History}

A detailed history of the patient was recorded as per the proforma

\section{Observations}

Total 15 patients were selected for the present study. Among them $11(73.33 \%)$ are male and $4(26.67 \%)$ are female (table-2). Among the different age groups majority patients $(6(40 \%))$ belong to the age group of 30-39 years (table-1). Majority (10(66.67\%) patients occupation is of sedentary (table-3). Only $4(26.67 \%)$ patients are smokers (table-4). Highest number $(6(40 \%))$ of patients are with in the chronicity of 612 months (table-5). Only 2 (13.33\%) patients are suffering from upper extremity ulcer and remaining 13 $(86.67 \%)$ are suffering from lower extremity ulcers (table-6). 10(66.67\%) patients are having twak mamsa adhishthana ulcers and remaining 5 $(33.33 \%)$ are having mamsa medho adhishthana ulcers (table-7). 15 patients are suffering from various sizes of ulcers and the average size of the wound of total patients is 6.433 squire centimeters (table-8). Majority of patients $9(60 \%)$ ) ulcers are non specific and remaining are diabetic, varicose and tropic (table-9).

Table: 1: Showing the distribution according to Age

\begin{tabular}{|l|l|l|l|}
\hline Sl.No & $\begin{array}{l}\text { Age Group (in } \\
\text { years) }\end{array}$ & No. of Patients & Percentage of Incidence \\
\hline 1 & $15-19$ & 1 & $6.667 \%$ \\
\hline 2 & $20-29$ & 1 & $6.667 \%$ \\
\hline 3 & $30-39$ & 6 & $40 \%$ \\
\hline 4 & $40-49$ & 4 & $26.667 \%$ \\
\hline 5 & $50-60$ & 3 & $20 \%$ \\
\hline Total & 15 & $100.000 \%$ \\
\hline
\end{tabular}


Table: 2: Showing the distribution according to Sex

\begin{tabular}{|l|l|l|l|}
\hline Sl.No. & Sex & $\begin{array}{l}\text { Total No. of } \\
\text { Patients }\end{array}$ & Percentage of Distribution \\
\hline 1 & Male & 11 & $73.33 \%$ \\
\hline 2 & Female & 4 & $26.67 \%$ \\
\hline Total & 15 & $100.00 \%$ \\
\hline
\end{tabular}

Table: 3: Showing the distribution according to Occupation

\begin{tabular}{|l|l|l|l|}
\hline Sl.No. & Nature of Work & $\begin{array}{l}\text { Total No. of } \\
\text { Patients }\end{array}$ & $\begin{array}{l}\text { Percentage } \\
\text { Distribution }\end{array}$ \\
\hline 1 & Sedentary & 10 & $66.67 \%$ \\
\hline 2 & Moderate Working & 3 & $20.00 \%$ \\
\hline 3 & Hard Working & 2 & $13.33 \%$ \\
\hline Total & 15 & $100.00 \%$ \\
\hline
\end{tabular}

Table 4: Showing the distribution according Habit of smoking

\begin{tabular}{|l|l|l|l|}
\hline Sl.No. & Habit of Smoking & Total No. of Patients & Percentage of Distribution \\
\hline 1 & Smoking & 4 & $26.67 \%$ \\
\hline 2 & Non-Smoking & 11 & $73.33 \%$ \\
\hline Total & & 15 & $100.00 \%$ \\
\hline
\end{tabular}

Table 5: showing the Incidence of Chronicity

\begin{tabular}{|l|l|l|l|}
\hline Sl.No. & Duration (in months) & No. of Cases & Percentage of Incidence \\
\hline 1 & $6-12$ & 6 & $40 \%$ \\
\hline 2 & $13-24$ & 5 & $33.33 \%$ \\
\hline 3 & $25-36$ & 3 & 20 \\
\hline 4 & $>37$ & 1 & $6.67 \%$ \\
\hline Total & 15 & $100 \%$ \\
\hline
\end{tabular}

Table 6: Showing Incidence of the site of Vrana

\begin{tabular}{|l|l|l|l|}
\hline Sl.No. & Site of Incidence & No. of Cases & Percentage of Incidence \\
\hline 1 & Upper Extremity & 2 & $13.33 \%$ \\
\hline 2 & Lower Extremity & 13 & $86.67 \%$ \\
\hline Total & 15 & $100 \%$ \\
\hline
\end{tabular}

Table 7: Showing the incidence of Adhishtana.

\begin{tabular}{|l|l|l|l|}
\hline Sl. No & Adhishtana & No. of Cases & Percentage \\
\hline 1 & Twak Mamsa & 10 & $66.67 \%$ \\
\hline
\end{tabular}




\begin{tabular}{|l|l|l|l|}
2 & Mamsa Medho & 5 & $33.33 \%$ \\
\hline Total & & $100 \%$ \\
\hline
\end{tabular}

Table: 8 showing the incidence of sizes of vrana

\begin{tabular}{|l|l|l|l|}
\hline Sl.No. & Size of Vrana in Squire Cm. & No. of Cases & Percentage of Incidence \\
\hline 1 & up to 2 & 2 & $13.33 \%$ \\
\hline 2 & $<2-4$ & 3 & $20 \%$ \\
\hline 3 & $<4-6$ & 5 & $33.33 \%$ \\
\hline 4 & $<6-8$ & 1 & $6.67 \%$ \\
\hline 5 & $>8$ & 4 & $26.67 \%$ \\
\hline Total & 15 & $100 \%$ \\
\hline
\end{tabular}

Table 9: Showing the incidence of Types of vrana

\begin{tabular}{|l|l|l|l|}
\hline Sl.No. & Types of Vrana & No. of Cases & Percentage of Incidence \\
\hline 1 & Diabetic Ulcers & 2 & $13.33 \%$ \\
\hline 2 & Varicose Ulcers & 3 & $20 \%$ \\
\hline 3 & Trophic Ulcers & 1 & $6.67 \%$ \\
\hline 4 & Non-Specific Ulcers & 9 & $60 \%$ \\
\hline Total & & 15 & $100 \%$ \\
\hline
\end{tabular}

Results: (Figure 7-8)

Table 10: Showing the percentage of relief on over all parameters:

\begin{tabular}{|l|l|l|l|l|}
\hline $\begin{array}{l}\text { Sl. } \\
\text { No }\end{array}$ & Parameters & $\begin{array}{l}\text { Total score Before } \\
\text { Treatment }\end{array}$ & $\begin{array}{l}\text { Total score After } \\
\text { Treatment }\end{array}$ & $\begin{array}{l}\text { Percentage of } \\
\text { relief }\end{array}$ \\
\hline 1 & Pain & 45 & 9 & $80.00 \%$ \\
\hline 2 & Pus discharge & 41 & 11 & $73.17 \%$ \\
\hline 3 & Foul smell & 37 & 7 & $81.08 \%$ \\
\hline 4 & $\begin{array}{l}\text { Oedema/ } \\
\text { induration }\end{array}$ & 33 & 7 & $78.79 \%$ \\
\hline 5 & $\begin{array}{l}\text { Reduction of } \\
\text { ulcer }\end{array}$ & 300 & 105 & $65.00 \%$ \\
\hline 6 & Overall & 456 & 139 & $69.52 \%$ \\
\hline
\end{tabular}


Table 11: Showing the result of treatment

\begin{tabular}{|l|l|l|l|l|l|}
\hline \multirow{2}{*}{ Drugs } & \multicolumn{2}{|l|}{ Results of the treatment } \\
\cline { 2 - 5 } & Good & Fair & Poor & No & Total \\
\cline { 2 - 5 } & Resp. & Resp. & Resp. & Resp. & \\
\hline Dviavartita Bhrungaraja taila. & $\begin{array}{l}8 \\
(53.33 \%)\end{array}$ & $(33.33 \%)$ & $(6.67 \%)$ & $(6.67 \%)$ & $(100 \%)$ \\
& & & & & \\
\hline
\end{tabular}

Table 12: Showing the result of treatment

\begin{tabular}{|c|c|c|c|c|c|c|c|c|}
\hline \multirow[t]{2}{*}{ Symptom } & \multirow{2}{*}{$\begin{array}{l}\text { No. of } \\
\text { Observati- } \\
\text { ons }\end{array}$} & \multicolumn{3}{|c|}{ Mean grade score } & \multirow[t]{2}{*}{ S.D } & \multirow[t]{2}{*}{ S.E } & \multirow[t]{2}{*}{$\mathbf{t}$} & \multirow[t]{2}{*}{$\mathbf{P}$} \\
\hline & & B.T & A.T & $\begin{array}{l}\text { BT- } \\
\text { AT }\end{array}$ & & & & \\
\hline Pain & 15 & 3 & 0.6 & 2.40 & \pm 0.74 & 0.190 & 12.62 & $<0.0001$ \\
\hline Pus discharge & 15 & 2.73 & 0.73 & 2.00 & $\begin{array}{l} \pm \\
0.65\end{array}$ & 0.169 & 11.83 & $<0.0001$ \\
\hline Foul smell & 15 & 2.47 & 0.47 & 2.00 & \pm 0.65 & 0.169 & 11.83 & $<0.0001$ \\
\hline $\begin{array}{l}\text { Oedema/ } \\
\text { induration }\end{array}$ & 15 & 2.20 & 0.47 & 1.73 & \pm 0.59 & 0.153 & 11.31 & $<0.0001$ \\
\hline $\begin{array}{l}\text { Reduction of } \\
\text { ulcer }\end{array}$ & 15 & 20.00 & 7.00 & 13.00 & $\begin{array}{l} \pm \\
5.92\end{array}$ & 1.528 & 8.511 & $<0.0001$ \\
\hline Overall & 15 & 30.40 & 9.27 & 21.13 & \pm 7.26 & 1.874 & 11.28 & $<0.0001$ \\
\hline
\end{tabular}

\section{Discussion and Conclusion}

Dushta Vrana of Ayurvedic literature is akin to chronic infective wound/ ulcer. In the present study 15 patients were treated with Dviavartita Bhrungaraja tail external application for 60 days. Majority of these patients were undergone various pathological, biochemical and histological investigations and some of them are even advised for plastic surgery and skin grafting. Majority of these patients are very poor and spent lot of money for the treatment. Though as per modern medicine the patients of chronic infective wound/ ulcer are supposed to be investigated to rule out many underlying causes seldom the patients are able to bear the cost. In the present study majority of the selected patients have already undergone various investigations and finally diagnosed as non specific ulcers. 2 patients were known diabetics, 3 were suffering from varicose veins and obstructed circulation and one was diagnosed Tropic ulcer. Overall effect of treatment on all clinical parameters was found highly significant by statistical analysis and percentage of relief assessed by individual scoring. This highly significant effect of treatment can corroborated with the classical and contemporary scientific references indicating the wound cleaning, wound healing properties of Bhrungaraja (Eclipta alba Hassk).

Though effect of treatment on each clinical parameter is good and overall around $70 \%$ of relief was 
observed, effect of treatment on Diabetic ulcer was poor. After completion of 60 days of treatment among the 2 diabetic patients one got healing of $20 \%$ of ulcer and other $43 \%$. Overall effect on these patients was observed as $18.75 \%$ and $31.25 \%$ respectively.

In remaining 13 some of the patients got complete normalcy with in month. The patients who were not able to walk or stand on affected leg became capable of walking by the end of 60 days of treatment. As this is a simple medicine used externally, majority of patients who were in such a pity condition with much physical, mental and social burden and sufferings felt utmost happiness by the end of the treatment. By observing the results of the treatment and by sharing the happy moods of patients it can be concluded that the Dviavartita Bhrungaraja Taila can be used successfully for wound healing due to its good antibacterial and antiseptic activity. It also possesses soothing, cooling, anti-inflammatory properties, which also help to recover the wound. Further research on large number of patients with this formulation can give a definite positive conclusion for the sufferers of Dushta Vrana (chronic infective ulcer).

\section{References}

1. Sharma PV. Susruta's "Sushruta samhita Sutra sthana" (Vol-I) with English translation and Dalhana's commentary along with critical notes. Varanasi; Chowkhambha Visvabharathi publishers; p 241-242

2. Harish Chandra Singh Kushwaha, Agnivesa's Charaka Samhita Chikitsa sthana (2nd part) translation. Varanasi; Chowkhamba Orientalia; 2009. p 646

3. Sharma PV. Susruta's "Sushruta samhita chikitsa sthana" (Vol-II) with English translation and Dalhana's commentary along with critical notes. Varanasi; Chowkhambha Visvabharathi publishers; $\mathrm{p} 433$

4. Sharma PV. Dravyaguna Vignan 2nd Vol, $2^{\text {nd }}$ edition. Varanasi; Chowkhamba Bharati academy; 2006. p 124-125

5. Sharma PC, Yelna MB, Dennis TJ. Database on Medicinal plants used in Ayurveda Vol 2. New Delhi; CCRAS; 2002. p 113-114

6. Gyanendra Pandey. Wound healing drug therapy (Vranaropana ausadhi vijnanam). Varanasi; Chowkhamba Sanskrit Series Office; 2004. p 39140 
Figure 1

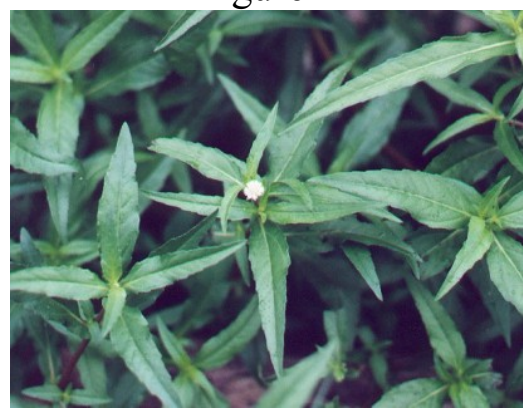

Figure 1: Bhringaraj plant

Figure 3

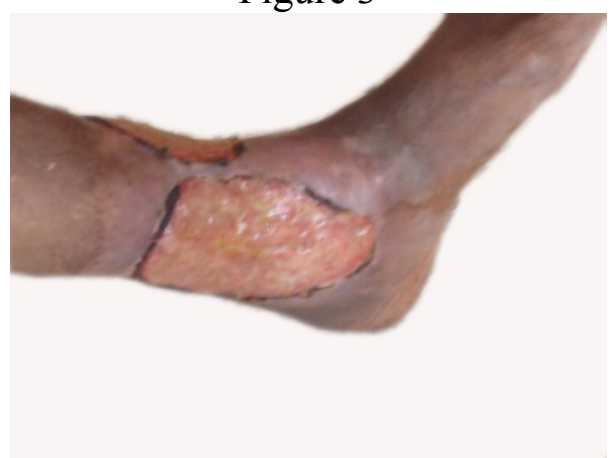

Figure 5

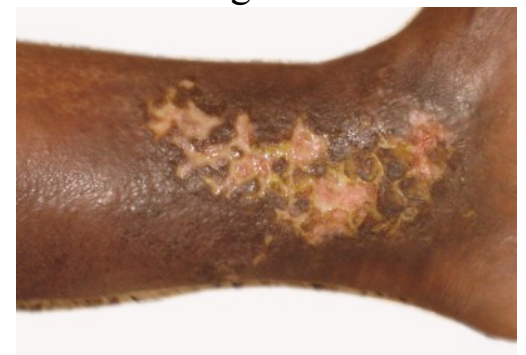

Figure 2

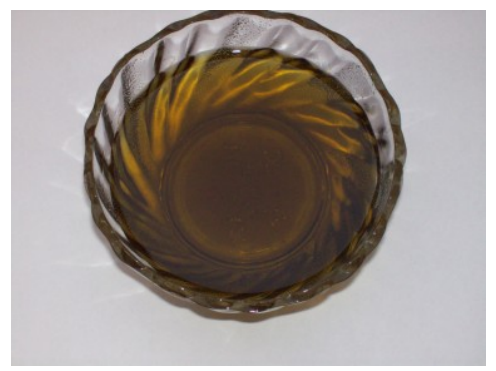

Figure 2: Bhringaraj taila

Figure 4

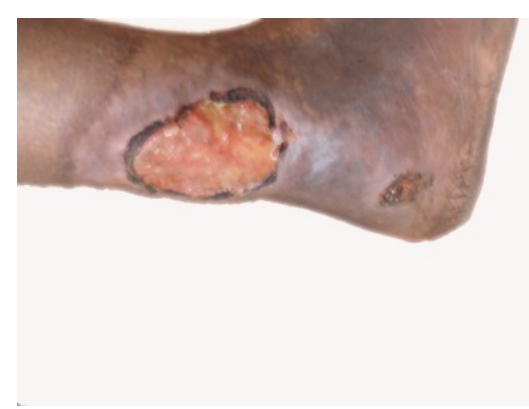

Figure 6

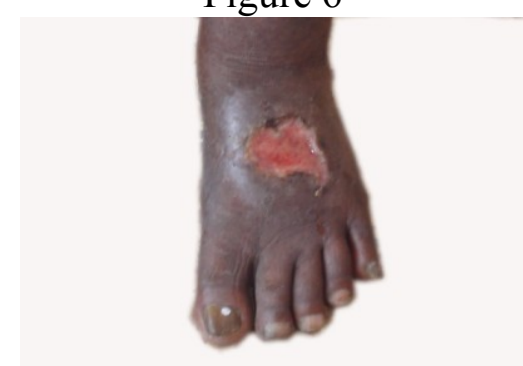

Showing the different patients with Chronic ulcers (Dushta vrana)

Figure 7

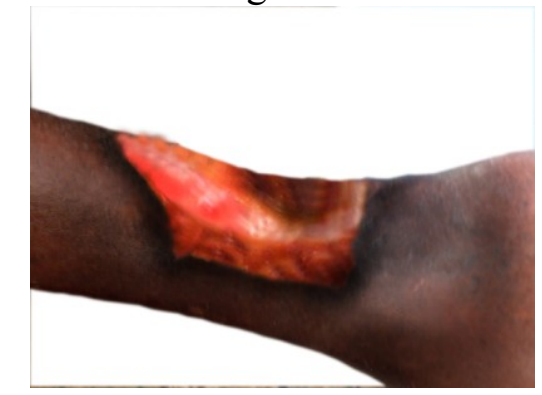

Before treatment
Figure 8

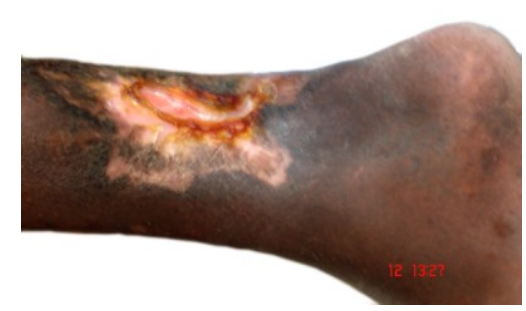

After treatment

Showing the ulcer in a patient before and after the treatment 